\title{
広東語話者による二字漢語の誤答の分析 \\ 一促音、濁音、半濁音に注目して一 \\ An error analysis of two-character Sino-Japanese words \\ by Cantonese speakers: Focusing on sokuon, dakuon and han-dakuon
}

郡司 拓也

嶺南大学

\section{要旨}

漢字圈学習者を対象とした漢字教育に関する研究は今日に至るまであまり多い とは言えない。実際の教育現場でも日本の漢字と学習者が母語で使用している 漢字の標準字形の違いについて触れる程度であるというところは少なくないよう に思われる。

本研究では漢字圈学習者である広東語母語話者がすでに持つ知識を日本語の 漢字語彙の習得に活用するための基礎調査の一つとして、二字の字音語（二字 漢語）の読みの誤りを分析した。促音、濁音、半濁音に関する誤答に注目した ところ、促音と濁音、特に濁音では本来音変化しないものまで過剰般化させる 誤りが多いということが明らかとなった。

キーワード:

広東語話者、二字漢語、音変化、誤答分析、過剰般化 


\section{広東語話者による二字漢語の誤答の分析 \\ 一促音、濁音、半濁音に注目して一}

\section{郡司 拓也 嶺南大学}

\section{1.はじめに}

日本語の漢字学習は非漢字圈学習者だけでなく、漢字圈学習者にとっても容易 ではないという指摘はしばしばなされている。例えば、伊藤（1989）は「漢字圈 学習者ですら閉口している点は、次の二つに要約できる。日本語の漢字の読みの 複雑さと、送り仮名の煩わしさである。と指摘している。そして前者に関し、 字音語の音変化について、「字音語の音変化の型といったものを学習者に提示 できれば、その読みを類推する手掛かりになるのではないか」とし、二字で構成 される字音語 (以下、「二字漢語」と表記) の音変化の法則について紹介している。

こうした字音語の音変化の法則はすでに数多く紹介されており、阿久津 (1991) のように漢字圈日本語学習者に対する教育を想定したものも見られる。

確かにこういった字音語の音変化の法則がわかれば、学習者の助けになるかも しれない。中でも漢字の知識のある漢字圈学習者、特に入声の区別のある広東語 話者にとっては促音化や半濁音化の区別の際に母語からの正の転移が期待できる 可能性はあるだろう。しかし濁音化など例外が見られるものも少なくないため、 ただそのまま法則を提示してもそれだけで効率的な語彙習得に繋がるから゙うか には疑問が残る。法則を提示する前に実際に学習者が字音語の音変化を本当に 苦手としているのか、苦手としているのであれば、その誤りに何らかの傾向が 見られるのかという点を把握することで、より効果的な文字、語彙教育に繋がる のではないかと考えたのが本研究の出発点である。

\section{2. 先行研究}

漢字の読みに関する誤答分析は濱田・高畠（2009）のように中国人学習者を 対象としたものを中心として、これまでも先行研究は少なくない。また兒島 (1998) のように香港の広東語話者を対象とした研究もある。濱田・高畠（2009）も兒島 （1998）も比率は異なるものの、ともに音韻に関しては長短音の誤り、清濁音の 誤り、子音の誤り（交替・添加・脱落など）が誤りの要因の上位 3 位であると 分析している。

こうした研究により、漢字の読みの誤りは学習者が音声面で苦手としている ものと共通する点が見られることが明らかにされている。 
しかしこれまでの漢字の読みに関する誤答分析は広く字音、字訓を含めて出題 し、音韻面での誤りや字音、字訓の混同など他の読みとの誤りに注目、分析して いるものが多く、二字漢語特有の音変化に注目している研究は少ないようである。 そのような中で、黒沢（2013）は二字漢語の前接字末音が入声音であるものに注 目し、漢字圈、非漢字圈学習者を含むN 2 レベルの学習者に対し、促音化、非促 音化の区別がどの程度できるのかという調査とその誤答分析（30 語、選択式）を 行い、誤答は母語を問わず、二字漢語の 2 字目（後接字）ではなく、1 字目（前 接字）に集中していたと述べている。しかし、この研究は促音化とそれに伴う半 濁音化に限定したもので、濁音化や前接字末音が入声音ではない半濁音化である ものに関しては対象外であり、二字漢語の促音化、濁音化、半濁音化に関する誤 答分析を行っている研究は少なくとも広東語話者を対象としたものではこれまで 行われていないようである。

\section{3. 研究の目的と方法}

本研究は広東語話者による日本語の二字漢語の習得過程において見られる 字音語の音変化に関する誤答を分析し、音変化を含むかどうかで誤答率に差が 見られるのか、また促音化、濁音化 (連濁)、半濁音化のそれぞれの誤答を比較し、 学習者の誤りの傾向を明らかにすることを目的とする。調査の手順は以下の とおりである。

\section{1 調查対象と調査の手順}

被験者はマカオ大学で日本語を専攻している広東語話者の 4 年生 39 名である。 被験者には事前に出題される二字漢語の一覧表を配布し、事前学習を促した上で、 毎回授業の最初の 5 分間を使い、二字漢語の文字・語彙の小テストとして解答 してもらった。

\section{2 再生テストの内容}

小テストとして実施した再生テストの出題語彙は『日本語能力試験出題基準 【改訂版】』に掲載されている語彙リストから旧日本語能力試験の 1 級相当の語彙 とされているものを抽出し、その中から二字漢語 577 語を調查対象とすることと した。その 577 語を原則として週 2 回の授業の際に毎回 30 語ずつ出題した。出題 方法は問題用紙に書かれている二字漢語を読み、その発音をひらがなで回答する というもので、極少数ながら見られたひらがなの字形の誤りによる誤答は今回の 調査対象外とした。なお本研究では二字漢語の音変化に注目をしているので、 二字漢語の前接字末尾音と後接字頭音以外の誤りに関しては誤答として扱わない。 


\section{4. 分析結果と考察}

\section{表 1. 二字漢語の延べ誤答数と 1 語あたりの平均誤答数}

\begin{tabular}{|c|c|c|c|}
\hline & 出題語数 & 延べ誤答数 & 平均誤答数 \\
\hline すべての二字漢語 & 577 & 1472 & 2.55 \\
\hline 音変化を含まない二字漢語 & 532 & 1308 & 2.46 \\
\hline 音変化を含む二字漢語 & 45 & 164 & 3.64 \\
\hline
\end{tabular}

再生テストの平均点は成績に影響するものであり、なおかつ日本語専攻の 4 年生 ということもあってか、毎回の得点率は 90\%を超えることがほとんどであった。 出題された二字漢語 577 語に対し、延べ誤答数は 1472 であり、1 語あたりの平均 誤答数は 2.55 であつた。そのうち音変化を含まない二字漢語の 1 語あたりの平均 誤答数は 2.46 であったのに対し、音変化を含むものは 3.64 となっており、音 変化を含む二字漢語の誤答率は含まないものに比べて高くなることが明らかと なった。

\section{1 必要な音変化ができていない誤答}

*括弧内は異なり語数

表 2. 音変化を含む二字漢語の誤答の傾向

\begin{tabular}{|c|c|c|c|c|c|}
\hline & $\begin{array}{c}\text { 音変化を } \\
\text { 含む } \\
\text { 出題語数 }\end{array}$ & $\begin{array}{c}\text { 音変化を } \\
\text { 含む延べ } \\
\text { 誤答数 }\end{array}$ & $\begin{array}{c}\text { 音変化が } \\
\text { できていない } \\
\text { 延べ誤答数 }\end{array}$ & $\begin{array}{c}\text { 音変化が } \\
\text { できていない } \\
\text { 誤答の割合 }\end{array}$ & $\begin{array}{c}\text { 音変化が } \\
\text { できていない } \\
\text { 平均誤答数 }\end{array}$ \\
\hline 促音化 & 29 & $110(73)$ & $34(25)$ & $30.91 \%(34.25 \%)$ & 1.17 \\
\hline 濁音化 & 8 & $16(14)$ & $6(6)$ & $37.5 \%(42.86 \%)$ & 0.75 \\
\hline 半濁音化 & 8 & $38(21)$ & $24(10)$ & $63.16 \%(47.62 \%)$ & 3 \\
\hline 総計 & 45 & $164(108)$ & $64(41)$ & $39.02 \%(37.96 \%)$ & 1.42 \\
\hline
\end{tabular}

音変化を含む二字漢語に限定して、その誤答の全体的な傾向を見てみると、音 変化を含む二字漢語の誤答 164 例のうち 64 例がその音変化が正しくできていない ことが要因の誤答であり、誤答全体の 39\%を占めた。音変化ができていない 1 語 あたりの平均延べ誤答数を比較すると、促音化が 1.17 、濁音化が 0.75 、半濁音 化が 3 となっており、このことから二字漢語の音変化の中では半濁音化が広東語 母語話者にとって間違いやすいという傾向がこの結果から読み取ることができる。

では促音化、濁音化、半濁音化のそれぞれについて、必要な音変化ができ なかった誤答例から、その誤答の傾向と要因を検討していく。 


\subsection{1 必要な促音化ができていない誤答}

表 3.必要な促音化ができていない誤答

\begin{tabular}{|c|c|c|c|c|c|}
\hline 語彙 & 漢字 & 延べ & 異なり & \multicolumn{2}{|c|}{ 誤答 } \\
\hline あつぱく & 圧迫 & 1 & 1 & あぱつ & \\
\hline がっしょう & 合唱 & 1 & 1 & がつしょう & \\
\hline がっち & 合致 & 1 & 1 & がつち & \\
\hline がっペい & 合併 & 1 & 1 & がつペい & \\
\hline くっせつ & 屈折 & 2 & 1 & くつせつ & けつしよ \\
\hline けっかく & 結核 & 1 & 1 & けつがく & \\
\hline けっしょう & 結晶 & 1 & 1 & けつしよう & \\
\hline げっぷ & 月賦 & 1 & 1 & げいぷ & \\
\hline さっかく & 錯覚 & 1 & 1 & さがく & \\
\hline しっきゃく & 失脚 & 2 & 1 & しきゃく*2 & しきゃく \\
\hline じっせん & 実践 & 3 & 2 & じせん*2 & じてん \\
\hline じったい & 実態 & 1 & 1 & じたい & \\
\hline せっちゅう & 折褁 & 1 & 1 & せいそう & \\
\hline ちつそく & 窒息 & 1 & 1 & ちそく & \\
\hline ちょつけい & 直径 & 3 & 1 & ちょけい*3 & \\
\hline てっこう & 鉄鋼 & 1 & 1 & てつこう & \\
\hline ひっしゅう & 必修 & 2 & 1 & ひしゅう*2 & \\
\hline ふっこう & 復興 & 2 & 2 & ふきょう & ふへん \\
\hline ふっとう & 沸騰 & 2 & 1 & ひとう*2 & \\
\hline みっしゅう & 密集 & 2 & 2 & みつしゅう & みしゅう \\
\hline みっせつ & 密接 & 4 & 2 & みつせつ & みせつ $* 3$ \\
\hline
\end{tabular}

まず必要な促音化ができていなかった誤答について見ていく。促音化ができて いなかった誤答を含む二字漢語は「圧迫」、「合唱」、「合致」、「合併」、「屈折」、 「結核」、「結晶」、「月賦」、「錯覚」、「失脚」、「実践」、「実態」、「折襄」、「窒息」、 「直径」、「鉄鋼」、「必修」、「復興」、「沸騰」、「密集」、「密接」の 21 語であった。

そこで見られた 34 の誤答（延べ誤答数）のうち、もっとも多く見られた誤答は

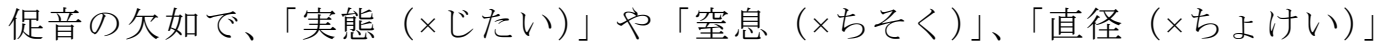




\section{広東語話者による二字漢語の誤答の分析}

一促音、濁音、半濁音に注目して一

のような誤答が 22 例見られ、必要な促音化ができていなかった誤答全体の $64.7 \%$ を占めた。恐らく2つの漢字が結合することによって、前接字末尾音が変化 することは認識しており、そのため前接字末尾音の「く」や「つ」を脱落させて いるのだろう。ただし、それが促音化であると認識していない、あるいは表記 の問題でなく、被験者が促音の発音が不得手であるため、促音の存在に気が 付かなかったため促音の「っ」が久如してしまったのではないかと思われる。

次に多く見られたのが「鉄鋼（xてつこう）」や「密接（xみつせつ）」のように 前接字末尾音が「つ」であり、本来促音化し、「つ」と表記す心゙きところを、「つ」 と書いているものが 7 例見られた。これに関しては被験者が促音化しないと考え て「つ」と書いたのか、それとも促音化させて「っ」と書いたつもりだが、書き 癖の問題で「つ」であると判断されたのか、その要因ははっきりしない。例えば、 「結晶 (xけつしよう)」のように促音の「つ」だけでなく、拗音の「ょ」も「よ」 と書いている誤答は書き癖が要因であると推測できるが、「密集（×みつしゅう）」 のような誤答もあり、この場合は「つ」は促音化しないと判断したものと推測 できるだろう。ただし、前述の「鉄鋼（×てつこう）」のような場合、文字から だけではその判別は困難である。

これに類似した誤答で、促音化はしているものの、促音の「っ」の代わりに、 「つ」を書いている誤答が見られた。「合唱（×がつしょう）」「合致（×がつち）」、 「合併 (×がつぺい)」の 3 例で、詳しく調べたところ、これらの誤答は 1 名の 被験者にのみ見られた傾向で、個人的な書き方の㾕で、促音の「っ」を大きく 書いてしまう癖があるだけで、本人は促音化をさせているつもりであることが、 後日確認できた。よって、この 3 例に関しては表記の問題であり、促音化が要因 の誤りではないと思われる。

それ以外には前接字末尾音を促音の「っ」ではなく、「い」に変化させる誤答が

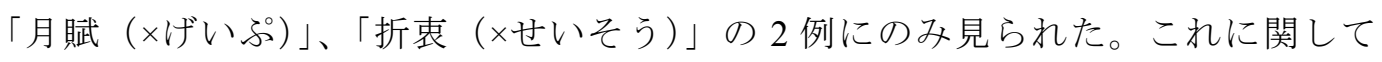
は、促音化ではなく、長音化させてしまったのかもしれないが、要因はよく わからなかった。

以上から必要な促音化ができていない誤答の要因は主に促音の欠如であること が明らかとなった。 


\subsection{2 必要な濁音化ができていない誤答}

表 4 . 必要な濁音化ができていない誤答

\begin{tabular}{|c|c|c|c|c|}
\hline 語彙 & 漢字 & 延べ & 異なり & 誤答 \\
\hline おうごん & 黄金 & 1 & 1 & おうこん \\
\hline かんじん & 肝心 & 1 & 1 & かんしん \\
\hline こうずい & 洪水 & 1 & 1 & こうすい \\
\hline しぼう & 脂肪 & 1 & 1 & しほう \\
\hline ちんぎん & 賃金 & 1 & 1 & ちんきん \\
\hline ゆうずう & 融通 & 1 & 1 & ゆうつう \\
\hline
\end{tabular}

次に必要な濁音化ができていなかった誤答について見ていく。濁音化ができて いなかった誤答を含む二字漢語は「黄金」、「洪水」、「脂肪」、「賃金」、「融通」、「肝 心」の 6 語であった。

そこで見られた 6 の誤答（延べ誤答数）はすべて単純に濁音化ができていない

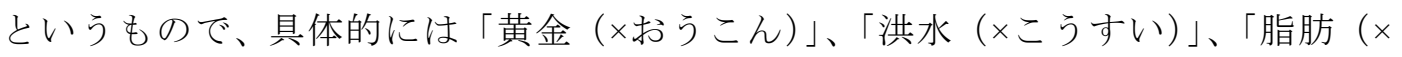

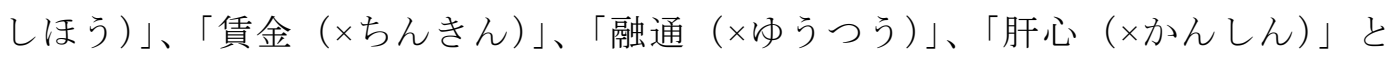
いうように二字の漢字をそのまま音変化させずに接続していた。

有声音、無声音が弁別性を持たない広東語母語話者にとって、カ・サ・タ・八 行の清音、濁音の区別が不得手であることは広く知られており、その影響で 清濁を混同してしまった可能性も考えられるが、単純に覚える段階で間違えた、 あるいは回答の段階で書き間違えた可能性も否めない。

\section{1 .3 必要な半濁音化ができていない誤答}

表 5 . 必要な濁音化ができていない誤答

\begin{tabular}{|c|c|c|c|c|}
\hline 漢字 & 延べ & 異なり & \multicolumn{2}{|c|}{ 誤答 } \\
\hline 圧迫 & 1 & 1 & あっばく & \\
\hline 運搬 & 5 & 1 & うんばん*5 & \\
\hline 合併 & 2 & 2 & かっべい & がっべい \\
\hline 月賦 & 8 & 2 & げっぶ*6 & げっぼう*2 \\
\hline 神秘 & 3 & 1 & しんび*3 & \\
\hline 船舶 & 2 & 2 & せんばく & せんばつ \\
\hline 頻繁 & 3 & 1 & ひんばん*3 & \\
\hline
\end{tabular}




\section{広東語話者による二字漢語の誤答の分析 \\ 一促音、濁音、半濁音に注目して一}

最後に必要な半濁音化ができていなかった誤答について見ていく。半濁音化が できていなかった誤答を含む二字漢語は「圧迫」、「運搬」、「合併」、「月賦」、「神 秘」「船舶」、頻繁」の 7 語であり、そのうち「圧迫」と「月賦」は促音化に伴う 半濁音化であり、それ以外は後接字頭音が八行音の漢字が撥音「ん」の後で半濁 音化したものである。

そこで見られた 24 の誤答（延べ誤答数）は「圧迫（×あっばく）」や「運搬（× うんばん）」のようにすべて半濁音化ではなく、濁音化をしているというもので あり、促音「っ」の後の誤答は延べ語数で 11 例、撥音「ん」の後では 13 例見 られた。

必要な促音化ができていない誤答では促音の「っ」が脱落した誤答が多かった が、一部には促音化をせず、そのまま二字の漢字を接続しているものも見られた。 また必要な濁音化ができていない誤答ではすべて濁音化をせずそのまま二字の 漢字を接続していた。それらと比心゙、必要な半濁音化ができていなかった誤答に は二字の漢字をそのまま接続するという誤答が一つも見られなかったという点で 異なっている。これは「二字漢語では後接字頭清音（カ・サ・タ・八行音）が すべて濁音化する」という過剩般化が行われているのではないかと推測される。

\section{2 過剩般化による誤答}

\section{表 6 . 必要な音変化ができていない誤答と過剩般化をしている誤答の比較}

\begin{tabular}{|c|c|c|c|}
\hline & $\begin{array}{c}\text { 過剰般化による } \\
\text { 誤答が見られた } \\
\text { 出題語数 }\end{array}$ & $\begin{array}{c}\text { 過剩般化をしている } \\
\text { 延べ誤答数 } \\
\text { (異なり誤数) }\end{array}$ & $\begin{array}{c}\text { 必要な音変化が } \\
\text { できていない延べ誤答数 } \\
\text { (異なり誤数) }\end{array}$ \\
\hline 促音化 & 33 & $50(38)$ & $34(25)$ \\
\hline 濁音化 & 69 & $133(83)$ & $6(6)$ \\
\hline 半濁音化 & 10 & $15(11)$ & $24(10)$ \\
\hline 総計 & 112 & $198(132)$ & $64(41)$ \\
\hline
\end{tabular}

誤答の分析の中で非常に興味深かったのが本来音変化をしないはずの二字漢語 まで促音化や濁音化、半濁音化をさせてしまう過剩般化による誤答である。

表 6 の必要な音変化ができていない誤答数と過剩般化による音変化をしている 誤答数を比較したところ、延べ誤答数で約 3 倍も過剩般化をしている誤答が多い ことが明らかとなった。特に過剩般化による誤った濁音化は濁音化が必要なのに それができなかった誤答に比心゙、約 22 倍も誤りが多く観察され、際立っている。 
被験者は日本語専攻の大学 4 年生であり、これまでの学習経験から「後接字頭 清音が濁音化する」という現象を帰納的に習得したものと思われる。しかし今日、 濁音化が主に見られるのは和語であり、飛田（1966）などで指摘されているよう に、二字漢語の濁音化は特に近代以降減少している。鈴木（2016）によると、

『日本国語大辞典第 2 版』の見出し語に含まれる主な字音形態素の連濁率は 0〜 10\%程度であるという。主に和語において見られる濁音化（連濁）という現象 を二字漢語において過剰般化させていると思われる。

学習歴の長短などで傾向に違いが見られる可能性はあるが、中上級の漢字圈 学習者であれば、おそらく同様の傾向が見られると思われる。以下、過剰般化に よる促音化、濁音化、半濁音化による誤答についてそれぞれ詳しく見ていく。

\subsection{1 促音化の過剩般化による誤答}

表 7 : 促音化の過剰般化による誤答

\begin{tabular}{|c|c|c|c|c|l|}
\hline 語彙 & 漢字 & 延べ & 異なり & \multicolumn{2}{|c|}{ 誤答 } \\
\hline あっぱく & 圧迫 & 1 & 1 & あっばく & \\
\hline うんぱん & 運搬 & 5 & 1 & うんばん*5 & \\
\hline がっペい & 合併 & 2 & 2 & かっべい & がっべい \\
\hline げっぷ & 月賦 & 8 & 2 & げっぶ*6 & げっぼう*2 \\
\hline しんぴ & 神秘 & 3 & 1 & しんび*3 & \\
\hline せんぱく & 船舶 & 2 & 2 & せんばく & せんばっ \\
\hline ひんぱん & 頻繁 & 3 & 1 & ひんばん*3 & \\
\hline
\end{tabular}

まず促音化の過剰般化による誤答について見ていく。33 語で促音化の過剰般化

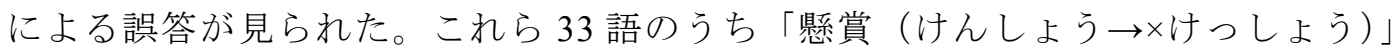

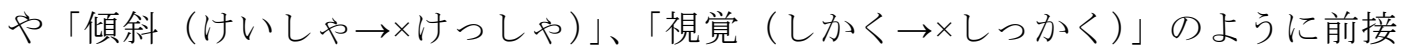
字末尾音が入声音ではないものが 21 語あった。また 33 語のうち 19 語は「閲覧(

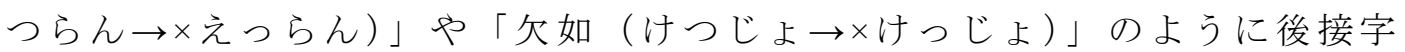
頭音がカ・サ・タ・八行音ではなかった。33 語のうち、前接字、後接字、あるいは その両方が該当するものが 30 語であり、残りの 3 語も「楽譜（がくふ）」「確保 (かくほ)」「蓄積（ちくせき）」であることから、「前接字末尾音が『(き・)く』 の場合、後接字頭音がカ行音のときに促音化する」という法則に該当しない。 つまり 33 語のすべてが促音化の法則に該当しないことが確認できた。促音化の 法則は濁音化のそれに比べると例外も少なく、法則を知ることで促音化の過剰 般化による誤りが避けられる可能性は高そうである。 


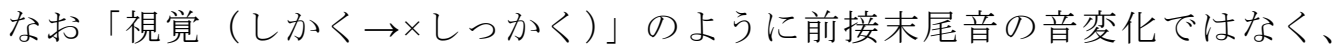
母音に促音の「っ」を加えてしまっている例が 14 語、異なり語数で 16 例見られた。

これは促音化の法則の問題ではなく、促音を含む音とそうでない音の区別がついて いないことによる誤答ではないかと思われる。また後接字頭音が濁音である語も

「削減（さくげん $\rightarrow$ さっげん）」のように 14 語あったが、これらも被験者が 清濁の区別ができていないことに要因があると思われる。つまり過剩般化による 誤りを避けるためには促音化の法則を知るだけではなく、変化する以前の漢字の 字音を知っていなければならないということを示していると言えよう。

\subsection{2 濁音化の過剩般化による誤答}

表 8. 濁音化の過剰般化による誤答

\begin{tabular}{|c|c|c|c|c|c|c|}
\hline 語彙 & 漢字 & 延べ & 異なり & \multicolumn{3}{|c|}{ 誤答 } \\
\hline あっぱく & 圧迫 & 1 & 1 & あっばく & & \\
\hline いけん & 異見 & 1 & 1 & いげん & & \\
\hline いんかん & 印鑑 & 2 & 1 & いんがん*2 & & \\
\hline いんき & 陰気 & 1 & 1 & いんぎ & & \\
\hline うんぱん & 運搬 & 5 & 1 & うんばん*5 & & \\
\hline えんかつ & 円滑 & 2 & 1 & えんがつ*2 & & \\
\hline がいとう & 街頭 & 1 & 1 & かいどう & & \\
\hline がいとう & 該当 & 1 & 1 & かいどう & & \\
\hline かくとく & 獲得 & 1 & 1 & かくどく & & \\
\hline がっペい & 合併 & 2 & 2 & かっべい & がっべい & \\
\hline がんこ & 頑固 & 1 & 1 & かんご & & \\
\hline ききん & 基金 & 1 & 1 & きぎん & & \\
\hline きゅうくつ & 窮屈 & 2 & 1 & きゅうぐう*2 & & \\
\hline きょうしゅう & 郷愁 & 4 & 2 & きょうじゅ & きょうじゅう*3 & \\
\hline きょうはく & 脅迫 & 1 & 1 & きょうばく & & \\
\hline きょくたん & 極端 & 3 & 2 & きょくだん*2 & きゃくだん & \\
\hline けいさい & 掲載 & 1 & 1 & けいざい & & \\
\hline けっかく & 結核 & 1 & 1 & けつがく & & \\
\hline けっしょう & 結晶 & 1 & 1 & けっじょう & & \\
\hline げっぷ & 月賦 & 8 & 2 & げっぶ*6 & げっぼう*2 & \\
\hline げんてん & 原典 & 1 & 1 & げんでん & & \\
\hline
\end{tabular}




\begin{tabular}{|c|c|c|c|c|c|c|}
\hline 語彙 & 漢字 & 延べ & 異なり & \multicolumn{3}{|c|}{ 誤答 } \\
\hline こうきょ & 皇居 & 1 & 1 & こうぎょ & & \\
\hline ごく & 語句 & 3 & 2 & こぐ*2 & ごぐ & \\
\hline さっかく & 錯覚 & 4 & 2 & さっがく*3 & さがく & \\
\hline ざひょう & 座標 & 1 & 1 & さびょう & & \\
\hline ざんこく & 残酷 & 1 & 1 & ざんごく & & \\
\hline しかく & 視覚 & 2 & 1 & しがく*2 & & \\
\hline しき & 指揮 & 1 & 1 & しぎ & & \\
\hline じき & 磁器 & 1 & 1 & しぎ & & \\
\hline じき & \begin{tabular}{|l} 
磁気 \\
\end{tabular} & 1 & 1 & しぎ & & \\
\hline じこ & 自己 & 6 & 3 & じご*4 & じごう & しご \\
\hline じっせん & 実践 & 3 & 2 & じっぜん*2 & しっぜん & \\
\hline しゅうし & 修士 & 1 & 1 & しゅうじ & & \\
\hline しゅし & 趣旨 & 1 & 1 & しゅうじ & & \\
\hline じょうし & 上司 & 1 & 1 & じょうじ & & \\
\hline じょうほ & 譲歩 & 3 & 3 & じょうぼ & しょうぼ & じょうぼう \\
\hline しんぴ & 神秘 & 3 & 1 & しんび*3 & & \\
\hline せいさい & 制裁 & 1 & 1 & せいざい & & \\
\hline ぜせい & 是正 & 1 & 1 & せぜい & & \\
\hline せんさい & 戦災 & 1 & 1 & せんざい & & \\
\hline せんとう & 戦闘 & 2 & 1 & せんどう*2 & & \\
\hline せんぱく & 船舶 & 2 & 2 & せんばく & せんばつ & \\
\hline だいたん & 大胆 & 4 & 2 & *2たいだん & だいだん & \\
\hline だけつ & 妥結 & 3 & 2 & だげつ*2 & だげき & \\
\hline たんか & 担架 & 1 & 1 & たんが & & \\
\hline ちょうかく & 聴覚 & 2 & 1 & ちょうがく*2 & & \\
\hline ちょっけい & 直径 & 1 & 1 & ちょっげい & & \\
\hline てっこう & 鉄鋼 & 1 & 1 & てっごう & & \\
\hline てんさい & 天災 & 3 & 1 & てんざい*3 & & \\
\hline とうち & 統治 & 4 & 1 & とうじ*4 & & \\
\hline ないかく & 内閣 & 5 & 1 & ないがく*5 & & \\
\hline
\end{tabular}




\begin{tabular}{|c|c|c|c|c|c|}
\hline 語彙 & 漢字 & 延べ & 異なり & & 誤答 \\
\hline ねんかん & 年鑑 & 1 & 1 & ねんがん & \\
\hline はかい & 破壊 & 2 & 1 & はがい*2 & \\
\hline はんしや & 反射 & 1 & 1 & はんじゃ & \\
\hline びんかん & 敏感 & 1 & 1 & ひんがん & \\
\hline ひんぱん & 頻繁 & 3 & 1 & ひんばん*3 & \\
\hline ふっこう & 復興 & 1 & 1 & ふつごう & \\
\hline ふっとう & 沸騰 & 1 & 1 & ふっどく & \\
\hline ふはい & 腐敗 & 1 & 1 & ふうばい & \\
\hline ふひょう & 不評 & 1 & 1 & ふびょう & \\
\hline ふんとう & 奮闘 & 1 & 1 & ふんどう & \\
\hline ベんかい & 弁解 & 1 & 1 & べんがい & \\
\hline へんかん & 返還 & 2 & 1 & へんがん*2 & \\
\hline ぼうちよう & 膨張 & 1 & 1 & ぼうじょう & \\
\hline ぼうとう & 冒頭 & 1 & 1 & ぼうどう & \\
\hline ほかく & 捕獲 & 2 & 1 & ほがく*2 & \\
\hline ほけん & 保険 & 1 & 1 & ほげん & \\
\hline ほしょう & 補償 & 1 & 1 & ぼじゅう & \\
\hline もほう & 模倣 & 6 & 1 & もぼう*6 & \\
\hline
\end{tabular}

次に濁音化の過剰般化による誤答について見ていく。69語で濁音化の過剰般化 による誤答が見られた。これら 69 語のうち「意見（いけん）」や「極端（きょく たん）」のうに前接字末尾音が広東語で m,n,ng 音ではないものが 41 語あった。 また 69 語のうち 7 語は 3.1 .3 必要な半濁音化ができていない誤答で観察された 本来、後接字頭音が半濁音化すべきところを濁音化させている誤りであり、うち

「運搬（うんぱん）」、「神秘（しんぴ）」、「船舶（せんぱく）」の４語は原則として 前接字末尾音が「ん」の場合、後接字頭音が八行音の漢字は濁音化ではなく、 半濁音化するという法則を知ることで比較的容易に避けられたように思われる。 前接字末尾音が広東語で m,n,ng 音ではない 41 語と撥音「ん」の後ろで半濁音化 すべき 4 語を合わせた 45 語は濁音化の過剩般化による誤答の $65.2 \%$ 占める。 促音化の過剰般化による誤答比べると、法則により誤りが避けられる割合はやや 低いが、これは現代日本語の字音語においては連濁をしない新しい語が多く、 例外が多いため、濁音化の法則からだけでは発音の判別がつきにくいことに起因 していると思われる。 


\section{2. 3 半濁音化の過剩般化による誤答}

表 9. 半濁音化の過剩般化による誤答

\begin{tabular}{|c|c|c|c|c|l|}
\hline 語彙 & 漢字 & 延べ & 異なり & \multicolumn{2}{|c|}{ 誤答 } \\
\hline おうぼ & 応募 & 3 & 1 & おうぽ*3 & \\
\hline かいぼう & 解剖 & 1 & 1 & かいぽう & \\
\hline けいぼつ & 刑罰 & 1 & 1 & げっぽつ & \\
\hline けつぼう & 欠乏 & 2 & 2 & けっぽう & けつぷ \\
\hline こうふん & 興奮 & 1 & 1 & こうぷ & \\
\hline こうぼ & 公募 & 1 & 1 & こうぽう & \\
\hline そくぼく & 束縛 & 1 & 1 & そくぽく & \\
\hline そぼく & 素朴 & 3 & 1 & そぽく*3 & \\
\hline ちんぼつ & 沈没 & 1 & 1 & ちんぽつ & \\
\hline びんぼう & 貧乏 & 1 & 1 & びんぽん & \\
\hline
\end{tabular}

最後に半濁音化の過剩般化による誤答について見ていく。10 語で半濁音化の 過剩般化による誤答が見られた。これら 10 語のうち 6 語は「応募（おうぼ）」、 「解剖（かいぼう）」、「刑罰（けいばつ）」、興奮（こうふん）」、「公募（こうぼ）」、 「素朴（そぼく）」であり、前接字末尾音が入声音や撥音「ん」ではなかった。 また 10 語のうち「興奮」の「奮（ふん）」を除く9 語は後接字頭音が半濁音化を する必要条件である八行音ではなく、バ行音であった。つまりこの二点から 10 語すべてが半濁音化の法則に合致しないことが明らかであり、例外も少ない ことから、促音化と同様に半濁音化に関しても法則を知ることで過剩般化による 誤りが避けられる可能性は高そうである。

\section{5. まとめ}

今回の研究結果から、まず音変化（促音化、濁音化、半濁音化）を含む二字 漢語は音変化を含まないものに比べて誤答率が高く、また音変化ができていない 誤答は半濁音化に関するものが他より多く見られるということも明らかとなった。 さらに音変化が正しくできていない誤答よりも、むしろ本来音変化をすべきでは ないものを過剩般化によって音変化をさせてしまう誤答のほうが多く観察され、 広東語母語話者の二字漢語の学習の際には過剩般化による音変化の誤り、特に 濁音化に関して注意が必要であることも明らかとなった。 


\section{広東語話者による二字漢語の誤答の分析}

一促音、濁音、半濁音に注目して一

今後は初中級レベルで扱われる二字漢語などにも調查対象の範囲を広げ、また 被験者も広東語母語話者だけでなく、入声音がない北京語母語話者との比較も試 みたい。さらに本研究で明らかとなった二字漢語の音変化に関する誤答、特に過 剰般化による誤答を事前に音変化の法則を導入することにより、誤答が減らせる かどうかという実践研究も行ってみたい。

\section{参考文献}

阿久津智（1991）「漢字圈の学生に対する漢字教育について」『筑波大学留学生教育センター 日本語教育論集』6,129-144.

伊藤芳照 (1989)「漢字の音訓」武部良明(編)『講座日本語と日本語教育 8 日本語の文字 . 表記（上）』明治書院，125-158.

黒沢晶子（2013）「漢字音教材開発一入声音を含む漢語の音変化をどう扱うか一」『日本語 教育方法研究会誌』20-1,62-63.

国際交流基金・日本国際教育協会 (2002) 『日本語能力試験出題基準【改訂版】』凡人社

兒島慶治（1998）「香港広東語話者への漢字の読み教育について一香港中文大学日本研究学科 の自作教材の分析を通して一」『日本学刊』2,1-28.

鈴木豊（2016）「字音形態素「ショ（所）」の連濁一「研究所」「保育所」を中心に一」『文京 大学外国語学部紀要』15,1-14

濱田美和・高香智美（2009）「中国人学習者に対する漢字教育のための基礎研究-漢字の読み・ 書きクイズにおける誤答の分析一」, 『富山大学留学生センター紀要』, 8,1-12.

飛田良文（1966）「明治大正時代における漢語の連濁現象」『東北大学日本文化研究所研究 報告』2,251-266. 